\title{
Danskerne og Rusland: Der plejer ikke at blive
} krig

Af Michael Hesselholt Clemmesen

Den dominerende danske opfattelse af truslen fra Rusland mod NATO-lande i Nordeuropa og det tilhørende konfliktscenarie er som følger: Putin har for at bevare magten valgt at satse på en gammeldags macho-markerende anvendelse af Ruslands begrænsede militære midler. Med trusler og misinformation søger han at intimidere og splitte NATO for at genetablere Ruslands retmæssige placering blandt verdens stormagter. Men da han er rationel, ved han, at det ville være katastrofalt for hans land, hvis han faktisk åbent angreb et NATO-land, fordi NATO samlet er så meget stærkere end Rusland.

Hvis det helt usandsynlige alligevel skulle ske, og Rusland invaderede Baltikum, vil baglandet Danmark ikke blive ramt direkte af andet end cyberangreb samt måske nogle konventionelle missiler fra Kaliningrad.

Danmarks bidrag i den usandsynlige situation vil blot være sikringen af vo- res territorium som base samt hele den lille danske felthærsrest, der så jævnfør regeringens udkast til forsvarsforlig kan opbygges på seks måneder. Mere kan man ikke forlange af vores lille land. Heller ikke hvis forventningen om en 'happy ending' for Vesten i krigen mod Rusland skulle vise sig for optimistisk. Vi plejer jo til sidst at blive reddet af venlige landes indsats uden væsentlig egen indsats.

Uanset at civile og uniformerede danske eksperter står bag denne mening, er den desværre overfladisk og grundfalsk.

\section{Ruslands styrke}

De danske og udenlandske analytikere, der følger den russiske militære udvikling tæt, konstaterer, at Rusland i løbet af de sidste 25 år og især siden 2008 gennem målbevist satsning ikke alene har nået amerikansk teknologisk niveau på centrale områder for styrkebalancen. Man har på væsentlige felter opnået klar overlegenhed, og i Østukraine og Syrien er dette delvis blevet testet og demonstreret.

Michael Hesselholt Clemmesen er pensioneret brigadegeneral og seniorforsker [emeritus] ved Forsvarsakademiets Institut for Militærhistorie og Krigsteori. Hans tjeneste i Forsvaret omfattede to år på Bornholm og blev afsluttet med ti år i Baltikum. Han har i næsten fyrre år været aktiv som kritisk sikkerhedspolitisk kommentator og strategihistorisk forsker og forfatter. 


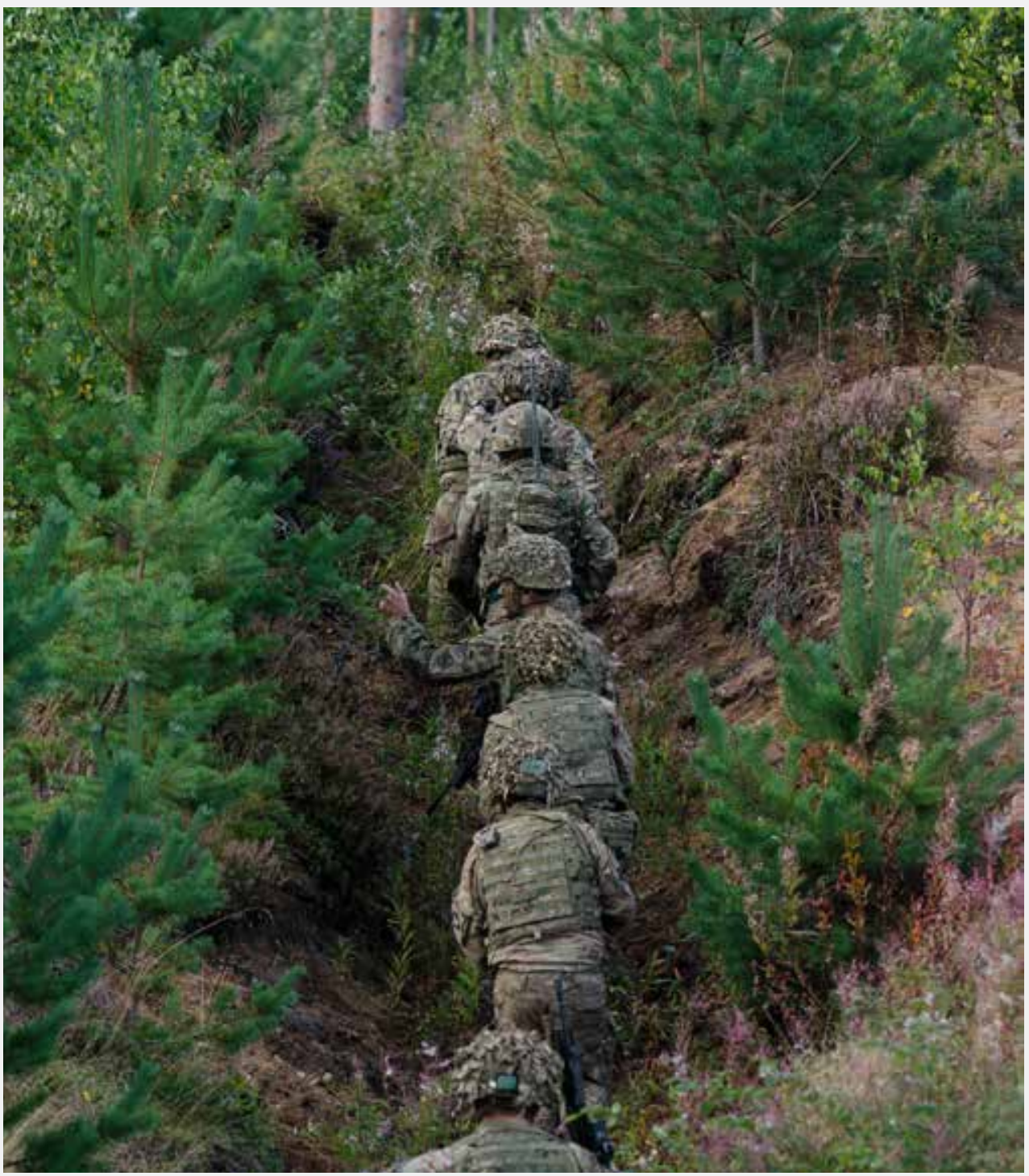

FOTO: LCpl Craig Williams via wikimedia commons

Britiske tropper på øvelse i Estland som led i NATOs fremskudte tilstedeværelse 
For de baltiske lande, Danmark og andre lande i Østersøområdet er det væsentligt, at Rusland har opnået overlegenhed med hensyn til luftværnsmissilsystemer, og afgørende, at man nu har langtrækkende sømålsmissiler, som Vestens flåder ikke har forsvarsvåben mod. De er bl.a. placeret på samme type lastvogne, der anvendes til langtrækkende krydsermissiler og ballistiske missiler, der kan være kernevåbenbærende.

Alle disse missiltyper er placeret fremskudt i Kaliningradprovinsen på trods af, at de her er direkte truet af den nu planlagte polske anskaffelse af amerikanske PATRIOT-luftværnsmissiler og HIMARS-raketartilleri.

\section{Russiske krigsforberedelser ligger fortsat helt i hænderne på en elite af veluddannede generalstabsofficerer med en igennem 150 àr udviklet, klassisk 'militærvidenskabelig' opfattelse.}

Et andet forhold, der nok er umuligt for de mange militært ukyndige vestlige eksperter at forstå, er, at russiske krigsforberedelser fortsat ligger helt i hænderne på en elite af veluddannede generalstabsofficerer med en igennem 150 år udviklet, klassisk 'militærvidenskabelig' opfattelse.

Den mulige konflikt analyseres for at skabe et godt doktringrundlag for opportunistisk udnyttelse af svaghed og blottelser. Forskellige handlemuligheder gennemtænkes og simuleres som af en dygtig skakspiller. Når egne svagheder erkendes i krigsspil eller de store, tilbagevendende krigsplansøvelser som ZAPAD 2017, tilpasses planlægning og de militære enheder hurtigt. Man er i modsætning til i Vesten akut bevidst om egne svaghe- der men tror alligevel, at der findes militære løsninger, hvis man dristigt og hensynsløst udnytter mulighederne. I Syrien fik de ret.

I Vesten domineres den sikkerhedspolitiske debat af teoretiske statskundskabsfolk med en arrogant afvisende holdning til bl.a. militær ekspertise og erfaring, som de finder anakronistisk, fordi de a priori ved, at gammeldags krige aldrig vil ske igen. Som det internationale diplomati til midt-juli 1914 ved de, at storkrig er ulogisk og derfor utænkelig.

\section{En Potemkin-landsby i forfald}

Jeg må chokere læserne med straks at understrege, at ingen hær har nogen som helst værdi i kamp eller til afskrækkelse af en kvalificeret modstander, hvis officerskorpset i en menneskealder ikke har fundet det relevant at tænke på, diskutere og realistisk øve storkrig og har afskaffet den nødvendige krigslogistik samt evnen til ligeværdig elektronisk krigsførelse.

Uanset hvor mange penge, der anvendes til at aflønne store afprofessionaliserede kadrer og deres kontraktsoldater, vil resultatet, hvis de møder virkeligheden, blive, som da asiatiske fyrsters moderne bevæbnede hære blev udslettet af europæisk kommanderede og disciplinerede styrker for 180-130 år siden.

Når man i diskussionen her i landet omtaler NATO, er det uanalytisk, ukritisk og uden ønske om at forstå ubehagelige realiteter. Som jeg for 30 år siden beskrev i Udenrigs (nr. 2, 1988) opfattes Alliancen som danskernes sikkerhedspolitiske Folkekirke, som vi forudsætter virker, når vi har brug for den.

Med NATO menes reelt USA, og vi gør os blinde for de siden 1990 gradvise amerikanske styrkereduktioner og materielnedslidning. Vi overser landets 


\section{Vi ignorerer også USA's demonstrerede manglende evne siden 1991 til at fastlægge og fastholde en realistisk strategi for anvendelse af sine og allieredes militære magtmidler.}

manglende økonomiske evne til at bevare mere end en begrænset del af dets militære styrke, og ignorerer det forhold, at USA på grund af forpligtelser i Asien og Stillehavet ikke kan gøre ret meget mere i Europa end nu, slet ikke uden et meget langt varsel. Vi ignorerer også USA's demonstrerede manglende evne siden 1991 til at fastlægge og fastholde en realistisk strategi for anvendelse af sine og allieredes militære magtmidler.

Fra begyndelsen af nullerne overbeviste vesteuropæiske NATO-lande sig om, at den del af historien, der indebar traditionelle krige i Europa, var slut. Fremtidens problem var reduceret til fjerne 'nye krige', og kun de gamle kolonimagter Frankrig og Storbritannien bevarede indtil besparelser nu små kapable ekspeditionsstyrker.

Samtidig omskabte de kontinentaleuropæiske medlemmer deres militære styrker til overbureaukratiserede hobbyklubber med meget store underbeskæftigede officerskorps med størst mulig jobsikkerhed og mindst mulig kritisk diskurs. Specielt i disse hære, med Bundesheer og den danske hær i front, blev de få generelle militære øvelser til drejebogstyrede rutineaktiviteter, hvis uddannelsesværdi også blev undergravet af arbejdstidsbestemmelser, arbejdsmiljø- og sikkerhedsrammen.

Logistik og støttefunktioner blev af liberale ideologiske modeårsager udliciteret, så de aldrig vil være til rådighed i krig. Dette sammen med afskaffelsen af de realistiske militære øvelser, nedbygningen af lagre af ammunition og reservedele, opløsning af reserveenheder samt hærofficerskorpsenes manglende intellektuelle energi og tro på egen relevans undergravede meget hurtigt hærenes evne til at gennemføre andet end symbolsk militær tilstedeværelse. Skulle de møde en kompetent modstander i højintensive kampoperationer, skal deres overlevelsestid tælles i timer.

Heldigvis ved de civile militæreksperter, at der aldrig bliver krig i Europa. Denne viden fik NATO til at forklare de østeuropæiske lande, herunder balterne, at medlemskab af Alliancen forudsatte, at de opgav ideen om territorialforsvar med dens værnepligt og reserver, panserværnsvåben og totalforsvarslogistik.

Mens de østeuropæiske lande efter opvågnen til den nye realitet siden 2014 forsøger at udbedre skaderne, er der ingen reelle tegn på, at de kontinentaleuropæiske medlemslande, herunder Danmark, vil gøre deres hære til andet end små puljer af mandskab og materiel til symbolsk grænsetilstedeværelse og små rutineøvelser inden for arbejdstiden. Når der aldrig igen bliver krig i Europa, er dette uproblematisk.

\section{Hvordan krige starter}

Forsvarets Efterretningstjeneste synes på grund af sine uanalytiske forudsætninger om NATOs styrke at udelukke muligheden for et russisk kupforsøg mod Baltikum, fordi dette, føler man, ville være irrationelt. Tjenesten antager, at krige vælges på grundlag af rationel analyse af muligheder og konsekvenser. Det er der desværre ikke noget historisk fundament for at tro.

Krigsmuligheden blev valgt som den 
mindst ringe mulighed bl.a. i 1863 af Danmark, i 1904 af Rusland, i 1914 af Østrig-Ungarn, i 1941 af først Tyskland mod Sovjetunionen og så Japan mod USA, i 1964 af USA i Vietnam, i 1979 af Sovjetunionen og i 2003 af USA. Det skete normalt i en kombination af tilfældigheder, egocentrisk fejllæsning af modstanderen, indenrigspolitisk tunnelsyn samt svigtende krav om professionel militær analyse med undervurdering af risici og oppustet opfattelse af egen styrke.

Lad os alligevel forudsætte, at en fremtidig russisk beslutning om at tage kontrol med Baltikum sker rationelt. Et forsøg er rationelt, hvis NATO ikke har rimeligt troværdige svar på russiske handlemuligheder. Kommer Rusland med et tilforladeligt 'fredstilbud', når de på et par uger har nået deres mål i Baltikum og måske også det østlige Polen, så stopper krigshandlingerne med en objektivt bedre russisk position til følge.

Et sådant forløb vil kunne ses som rationelt, fordi NATO i mange måneder nok flere år - ikke vil have styrker til en generobring af det tabte; fordi der ved en fortsættelse af krigen vil være akut risiko for en optrapning til kernevåbenanvendelse, hvilket Rusland vil understrege; fordi der ikke vil være enighed i Alliancen; og fordi USA's position indtil videre undergraves af landets ledelse.

Et sidste problem med den danske normalopfattelse er, at den ser på situationen i Europa isoleret. Uanset om en konfrontation indledes i Asien eller i Europa vil den skabe risiko for opportunistisk udnyttelse af situationen i den anden verdensdel. Som i Anden Verdenskrig er Asien og Europa knyttet sammen, og med USA's relative svækkelse vil fx en optrapning i Korea skabe en akut risiko i Europa. Udløseren af russisk handling over for Baltikum kan komme i Asien eller USA selv.

\section{Baltikum}

NATOs situation i Østersøområdet er nu præget af kombinationen af to næsten uløselige svagheder: For det første Alliancens meget lange landegrænse, der af hensyn til afskrækkelse skal kunne forsvares i mange uger måske måneder, indtil nordamerikansk hjælp kan nå frem. For det andet sårbarheden af søruterne i den sydlige Østersø.

Den klassiske tommelfingerregel, at en forsvarer kun behøver en tredjedel af angriberens styrke, er meningsløs i en situation med lav troppetæthed, specielt hvor forsvarets dybde er begrænset, og angriberen af politiske grunde har initiativet.

Den samlede baltiske landgrænse til Rusland og Hviderusland opgives til $1.660 \mathrm{~km}$, heraf mere end $800 \mathrm{~km}$ direkte til Rusland. Det er over $300 \mathrm{~km}$ længere end den finsk-russiske grænse, og den baltiske geografis forsvarsdybde og forsvarsværdi er betydeligt mindre end den finske. Ud over landgrænsen skal også den estiske nordkyst og landets øer, den sydlige litauisk-lettiske østersøkyst samt hovedstæderne og de primære havne sikres. Af landgrænsernes totale længde skønnes mellem 200 og $250 \mathrm{~km}$ at skulle gives et egentligt forsvar på grund af vejnettet eller kort afstand til hovedstæder, havne eller lufthavne.

I typisk baltisk grænseterræn vil selv en balanceret, moderne defensivt udrustet brigade, der kender området, har øvet i dette og forberedt forsvaret, ikke kunne forsvare mere end 10-12 km i bredden.

Forsvaret af de specielt truede ruter og afsnit i de tre baltiske lande ville derfor samlet kræve værdien af omkring 20 øve- 


\section{Balterne skulle alene stille småstyrker som solidaritetsmarkører i Allian- cens og USA's småkrige i fjerne lande. Balterne råder derfor i modsæt- ning til finnerne ikke over 900.000 uddannede reservister bag felthærs- brigaderne og evnen til om nødvendigt at forøge brigadernes antal.}

de brigader. Da disse så er disponeret, skal resten af grænsen samt truede kyster sikres af mindre stærke, hjemmeværnslignende lokalforsvarsenheder, der bakkes op af vel to mobile brigader per land.

For at opsummere den landmilitære dimension: Det minimale samlede styrkebehov for at kunne forsvare de tre baltiske lande er omkring 25-30 brigader, samlet 120.000 til 150.000 soldater. Hertil mindst yderligere 80.000 til 120.000 soldater i logistik, stabe og anden støtte fordelt mellem de baltiske lande og andre NATO-lande med styrker i Baltikum. Hvert baltisk land skal finde yderligere 20.000 til 50.000 lokalforsvarssoldater. Forsvaret af Baltikum mod Rusland kræver altså samlet set omkring 250.000 soldater og 100.000 hjemmeværnsfolk.

Dette antal svarer nogenlunde til det antal Sverige kunne mobilisere under den kolde krig, og som Finland fortsat har på dages til ugers beredskab. Med andre ord kunne det direkte baltiske forsvarsproblem teoretisk løses som det finske, der med et forsvarsbudget, der svarer til det danske, med 230.000 soldater i front og yderligere 500.000 lokalforsvarsstyrker realistisk gør et russisk lynangreb meget risikabelt og et velforberedt russisk angreb ekstremt bekosteligt.

Også NATO-lande kunne som tidligere udskrive civilt materiel til enhederne og have uddannede kadrer og mandskab til at møde på 24-48 timer, men så skulle man indse og forklare, at historien ikke er slut.

Af det skitserede styrkebehov vil balterne om nogle år maksimalt kunne dække en fjerdedel, da de mangler materiel og uddannede kadrer og personel til mere. Dette også på grund af den beskrevne anakronistiske NATO-rådgivning for tyve år siden mod værnepligt og samfundsforankret territorialforsvar.

Balterne skulle alene stille småstyrker som solidaritetsmarkører i Alliancens og USA’s småkrige i fjerne lande. Balterne råder derfor i modsætning til finnerne ikke over 900.000 uddannede reservister bag felthærsbrigaderne og evnen til om nødvendigt at forøge brigadernes antal. Det resterende behov, omkring 20 brigader, må derfor dækkes af allierede styrker, der i alt væsentligt må ankomme og støttes ad søvejen. Transport over landegrænsen fra Polen er ikke sikker og lufttransport kan kun levere lette enheder til kortvarig indsats uden logistik.

\section{Østersøen og Bornholms rolle}

Mulighederne, for at NATO kan støtte Baltikum ad søvejen i en krise og konflikt med Rusland, afhænger af, om skibskonvojer kan sikres mod truslen fra miner, ubådstorpedoer samt og ikke mindst sømålsmissiler affyret fra skibe, fly samt lastvogne og raketbatterier skjult $i$ anonyme skibscontainere på skibe og i land.

Den største trussel mod NATOs mulighed for at sejle i Østersøen er de moderne BASTION-sømålsmissilbatterier i Kaliningrad, der ikke kan sættes ud af spillet, dels fordi det forudsætter en optrapning til angreb på russisk jord, dels fordi det er vanskeligt at finde og med sikkerhed identificere raketbatterierne og dette helst uden at forveksle dem med måske kernevåbenudrustede ISKANDER-missiler. 
For at NATO kan udnytte søruterne i Østersøen kræver det en fase med forudgående angreb med fly på Kaliningrad og ikke mindst bekæmpelse af raketbatterierne fra Polen og Litauen med kanoner samt de langtrækkende våbensystemer, som Polen nu køber til flyvevåbnet og hæren.

\section{At satse på, at de russiske militære planlæggere ikke kan se den direkte og tætte sammenhæng mellem sikring af Baltikum og den danske ø Bornholm er ikke kun naivt, men amatøragtigt.}

Kaliningrads geografisk isolerede situation gør det indlysende vanskeligt for Rusland at opnå en varig blokering af vestlig anvendelse af søruterne. Derfor presses Rusland af de igangværende NATO-forsvarsskridt til at skaffe sig mindre sårbare placeringer for dets missilbatterier. Tre muligheder herfor tegner sig, den estiske ø Saaremaa, Gotland samt Bornholm.

Kuperobring af det sydlige Gotland eller specielt Bornholm tidligt i konflikten vil give Rusland sikrede baser for landets mange og effektive missilsystemer, hvor NATO ingen modtræk har. Især er Bornholm blevet mere attraktiv, da øen i modsætning til Gotland og Saaremaa dels er uforsvaret, dels kan besættes uden de negative virkninger af en operation mod Gotland, der med sikkerhed vil bringe Sverige ud at neutraliteten og udløse den igen forberedte amerikanske flydeployering til svenske flyvepladser.

\section{Efterretningstjenestens uansvarlighed}

At satse på, at de russiske militære planlæggere ikke kan se den direkte og tætte sammenhæng mellem sikring af Baltikum og den danske ø Bornholm er ikke kun naivt, men amatøragtigt.

Traditionelt anvendte efterretningstjenester ordet 'mulighed' i diskussionen af truslerne og gav ved sin tilknyttede analyse de politiske og militære beslutningstagere en central del af grundlaget for at beslutte eller afvente. Denne tilgang markerede den realitet, at efterretningstjenester ikke kunne eller burde tage ansvaret for de politisk ansvarlige og militært operative myndigheders anvendelse af dens vurderinger.

Den tidligere velbegrundede forsigtighed med at træffe beslutninger på vegne af de ansvarlige er nu fortid. Forsvarets Efterretningstjeneste skrev i 2016 i overensstemmelse med ny praksis: "Rusland vil ikke tage politiske og militære initiativer, som ledelsen vurderer, har en høj risiko for at kunne føre til en direkte militær konfrontation med NATO. Det er derfor usandsynligt, at Rusland vil foretage et militært angreb på de tre baltiske lande" (FE, Efterretningsmæssig Risikovurdering 1.12.2016, p. 12).

Ved at sælge forudsigelser som sikkert beslutningsgrundlag og anvende sandsynligheder går man langt videre, idet man reelt lader som om, at efterretningstjenester har kompetence til at tage ansvaret. Reelt lader man som om, at tjenesten kan tage ansvaret fra politikere og de operativt ansvarlige med observationer, hvis fundament er forventningen om, at alle politiske beslutninger er logiske og lineære, som i det konkrete tilfælde blot er en arrogant fastlæggelse af, at det ikke plejer at gå galt.

Tjenester anlægger denne tilgang i en tid, der domineres af brud med, hvad der plejer af ske, bl.a. ved migrationsbølger, britiske folkeafstemninger, amerikanske valg, Tyrkiets halve brud med NATO, 
udfaldet af den syriske borgerkrig og den chokerende udvikling i Nordkoreas militære kapacitet.

Ved at gå fra 'mulighed' til 'sandsynlighed' på et grundlag af ren situationsfremskrivning fritager efterretningstjenester beslutningstagerne for ansvarlighed, men uden selv at kunne påtage sig denne, hvis man ikke overlever til en eventuel efterkrigskommission.

Det er klart, at Forsvarets Efterretningstjeneste med sit nu demilitariserede organisatoriske fokus reelt er en udlandsefterretningstjeneste, der af indenrigspolitisk bekvemmelighed fortsat er finansieret af forsvarsministeriet. Tjenesten har i dette forløb fravalgt evnen til militærfaglig vurdering af et land som Rusland, der af - for vesteuropæere - uforståelige årsager har valgt at lade sin udenrigspolitik styre af en anakronistisk militærvidenskabelig logik.

Udviklingen understreges af, at tjenestens centrale rapporter ikke længere formelt er forsvarschefens ansvar. Som den øverste militære chef havde han tidligere det væsentlige ansvar at koble analyser af truslen sammen med en professionel dybdeforståelse af egen sides styrke og svagheder, som truslen var rettet mod. Hvordan dette kunne og burde ske, blev illustreret under Forsvarskommissionen af 1988's udredningsarbejde. Denne rolle er ikke længere placeret hos den me- get rutinerede forvalter i stillingen, og det er uklart om nogen fagperson længere har ansvaret og derfor også skal opretholde viden om en større krigs krav til forsvaret.

Forsvarets Efterretningstjenestes anvendelse af ordet 'risiko' som en substitut for mulig trussel sker overfladisk, dvs. at man undlader en grundig analyse af hvordan Danmark konkret vil blive ramt/påvirket, så man kan skabe fundamentet for forsvarstiltag. Dette er nok årsagen til, at Danmark i modsætning til Sverige ikke forstår de konkrete russiske behov for $\mathrm{i}$ en sikkerhedspolitisk krise at 'låne' vores strategisk beliggende $\emptyset$ i Østersøen.

Det nu næsten fraværende militære element må være grunden til, at risikovurderingens diskussion af cybertruslen fokuserer på cyberspionage og -kriminalitet snarere end på det russiske totalangreb på centrale dele af den danske finansielle, transportmæssige og sundhedsmæssige it-infrastruktur, som efter erfaringerne fra Ukraine vil kunne ramme Danmark i en krise. Det er forståeligt, at nationalbankdirektøren for nyligt i Berlingske Tidende gjorde sin nervøsitet for et cyberangreb på bl.a. Nets klar.

Danmark spiller ligesom NATOs flertal ludo, hvor intet kan forudses, og ingen kan ansvarliggøres for udfaldet, mens Rusland spiller skak. 